Riser, M., Géraud, J., Rascol, X., Riser, A. \& SaintMARC, M. (1957) Syndrôme de Guillain-Barré et Strohl à évolution ascendante avec hypertension intra-crânienne. Bulletin et Mémoires de la Société médicale des Hôpitaux de Paris, 73, 689.

Saracco, J.B., Genevet, J. \& Mouly, A. (1971) Atrophie optique et dissociation albumino-cytologique. Bulletin des sociétés d'ophtalmologie de France, 71, 637.
TAYlor, E.W. \& McDonald, C.A. (1932) The syndrome of polyneuritis with facial diplegia. Archives of Neurology and Psychiatry, 27, 79.

WloDARCZYCK, S. (1949) Un cas de syndrôme de GuillainBarré avec névrite optique rétrobulbaire. Neurologia, neurochirurgia; psychiatria polska, 23, 110.

\title{
Osteomalacia associated with increased renal tubular resorption of phosphate (hypohyperparathyroidism)
}

\author{
J. A. Kanis \\ B.Sc., M.B., Ch.B., M.R.C.P. \\ R. J. WALTON \\ B.Sc., M.B., B.S., M.R.C.P. \\ Metabolic Units, Western General Hospital, Edinburgh, and Nuffield Orthopaedic Centre, Oxford
}

\section{Summary}

A 12-year-old girl, who presented with joint pains, was found to have hypocalcaemia, hyperphosphataemia due to increased renal tubular reabsorption, increased serum alkaline phosphatase activity, and osteomalacia. These features, which resemble those found in socalled hypohyperparathyroidism, were all rapidly reversed by small doses of cholecalciferol.

\section{Introduction}

Costello and Dent (1963) suggested the term hypohyperparathyroidism to describe the apparent co-existence of parathyroid overactivity and diminished renal responsiveness to parathyroid hormone (PTH) in a seven-year-old girl with normal glomerular function and with no stigmata of pseudohypoparathyroidism. Biochemical hypoparathyroidism was inferred from the low serum calcium (Ca) and high serum inorganic phosphate (Pi), whilst typical $X$-ray changes and increased activity of serum alkaline phosphatase (SAP) suggested parathyroid overactivity. Allen, Millard and Nassim (1968) reported increased osteoid in a bone biopsy specimen from a similar patient. Recently, a twelveyear-old girl with similar features has been studied, and her response to cholecalciferol is reported.

\section{Case report}

A 12-year-old female Indian immigrant, who had lived in Scotland for the previous 4 years, presented in April 1973 with a 4-week history of pain

Correspondence: Dr J. A. Kanis, Nuffield Orthopaedic Centre, Headington, Oxford OX3 7LD. in the knees. She had previously been in good health and her menstrual periods had just begun. She was of normal height $(150 \mathrm{~cm})$ and weight $(40 \mathrm{~kg})$, and secondary sex characteristics were present. Chvostek's sign was present but there were no other abnormal features on examination.

Results of investigations were as follows: chromosomal karyotype was that of a normal female; serum $\mathrm{Ca}$ was low and plasma Pi was increased (Table 1); SAP activity was 427 iv/l, which is markedly elevated for a girl of this age (Clark and Beck, 1950; Round, 1973), and qualitative electrophoresis showed that this increased activity was of bony origin; plasma urea, creatinine, magnesium and other electrolytes were normal; there was no amino-aciduria, glycosuria or proteinuria; the urinary excretion rate of calcium was very low, $0.7 \mathrm{mEq} / 24 \mathrm{hr}$; the estimated maximum renal tubular resorption of phosphate per unit of glomerular filtration rate $\left(\mathrm{Tm}_{\mathrm{P}} / \mathrm{GFR}\right)$ (Bijvoet and Morgan, 1971) was markedly elevated (Table 1); urine acidity after oral ammonium

TABLE 1. Investigations before and during treatment with cholecalciferol

\begin{tabular}{lccc}
\hline & $\begin{array}{c}\text { Before } \\
\text { treatment }\end{array}$ & $\begin{array}{c}\text { After 6 } \\
\text { weeks of } \\
\text { treatment }\end{array}$ & $\begin{array}{c}\text { Normal } \\
\text { adult } \\
\text { range }\end{array}$ \\
\hline Serum Ca (mEq/1) & $3 \cdot 4$ & $4 \cdot 5$ & $4 \cdot 5-5 \cdot 0$ \\
Plasma Pi (mg/100 ml) & $6 \cdot 0$ & $4 \cdot 9$ & $2 \cdot 7-4 \cdot 5$ \\
SAP (iu/l) & 355 & 210 & $25-85$ \\
Serum 25-OHD (ng/ml) & $<0 \cdot 8$ & 25 & $4-23$ \\
Serum PTH (ng/ml) & $2 \cdot 0$ & $<0.9$ & $<0 \cdot 9$ \\
TmP/GFR (mg/100 ml) & $7 \cdot 4$ & $4 \cdot 2$ & $2 \cdot 5-4 \cdot 2$ \\
\hline
\end{tabular}




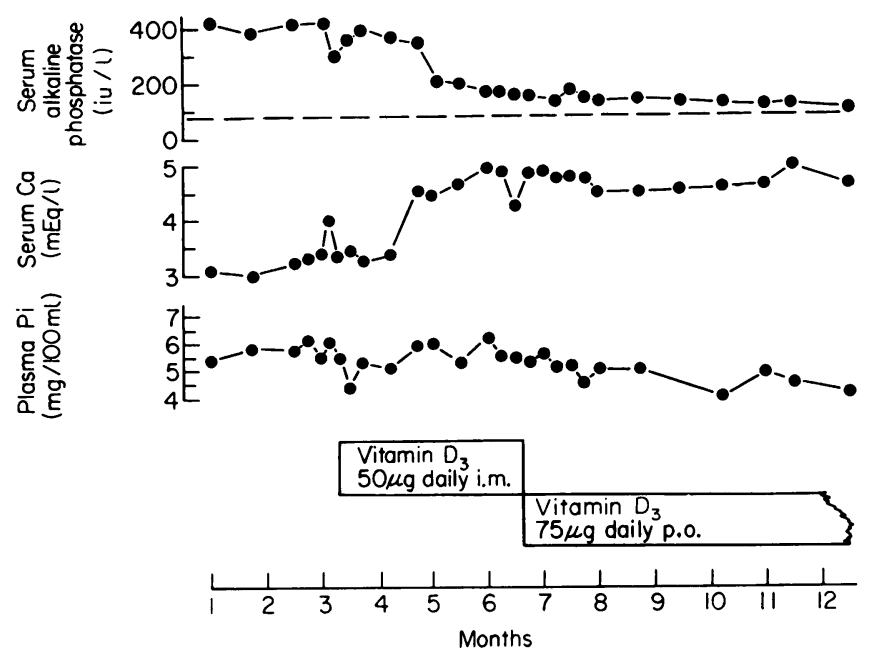

Fig. 1. Serial determinations of serum Ca, plasma Pi and SAP before and during treatment with cholecalciferol.

chloride (Wrong and Davies, 1959) and urine osmomolarity after overnight fluid deprivation were normal.

$X$-rays of the hands and wrists showed normal bone age but widening of the radial and ulnar epiphyses and sub-periosteal erosions of the phalanges; examination of a bone biopsy specimen from the iliac crest revealed abnormally wide osteoid seams on trabecular surfaces, characteristic of osteomalacia; there was evidence of active bone formation and resorption but not of osteitis fibrosa.

Serum 25-hydroxy vitamin D (25-OH D) (Preece et al., 1974) was undetectable when serum immunoreactive PTH (Addison et al., 1971) was elevated and serum calcium was low (Table 1); there was no evidence of generalized intestinal malabsorption; daily dietary intake was estimated to be $1.7 \mathrm{~g}$ of $\mathrm{Ca}$, $1.9 \mathrm{~g}$ of $\mathrm{P}$ and $5 \mu \mathrm{g}$ of vitamin $\mathrm{D}$.

Treatment with cholecalciferol, 50-75 $\mu \mathrm{g}$ daily, led to a rise in serum $\mathrm{Ca}$ and a fall in plasma $\mathrm{Pi}$ and SAP (Fig. 1). Six weeks after beginning treatment, she was symptom-free, and $\mathrm{Tm}_{\mathrm{P}} / \mathrm{GFR}$, serum PTH and serum 25-OHD were all normal (Table 1). Following an injection of PTH, urinary cyclic-AMP excretion increased from 2.0 to $22.7 \mathrm{nmol} / \mathrm{min}$, suggesting that the renal response to PTH was normal at this stage (Chase and Aurbach, 1967). Eight months after starting treatment, hand and wrist $\mathrm{X}$-rays were normal.

\section{Discussion}

The main clinical features of this patient were very similar to those of two previously reported cases of hypohyperparathyroidism (Costello and Dent, 1963; Allen et al., 1968). Development was normal, there was hypocalcaemia, hyperphosphataemia and in- $\stackrel{ }{\rightarrow}$ creased SAP activity, X-rays showed rachitic changes $\bar{z}$ and cortical erosions, and there was histological evidence of osteomalacia in the two patients on $\vec{\theta}$ whom bone biopsies were performed. Such changes oै are found in chronic renal failure and pseudohype parathyroidism, but there was no evidence of eithe condition in these patients.

Since the assay for vitamin $D$ measures the 25 hydroxy derivatives of both $D_{2}$ and $D_{3}$, the low serum level, in the absence of intestinal malabsorp- $\stackrel{\AA}{\varrho}$ tion syndrome, suggests that this patient had a $\overrightarrow{0}$ dietary deficiency of vitamin $\mathrm{D}$, and that the dieti- 3 cian's assessment was in error.

The pre-treatment plasma $\mathrm{Pi}$ (mean $5.6 \mathrm{mg} / 100$. $\mathrm{ml}$ ) is probably within the normal range for a girl of 흔 this age (Greenberg, Winters and Graham, 1960; Round, 1973) but is unexpectedly high in a patient with vitamin $\mathbf{D}$ deficiency and secondary hyperparathyroidism. This high plasma $\mathrm{Pi}$ was due to a high setting of renal tubular resorption, suggesting un-

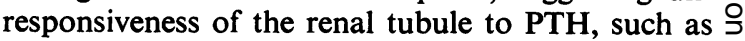
occurs in the inherited condition of pseudohypo- $\rightarrow$ parathyroidism. The fall in plasma $\mathrm{Pi}$ when the patient was given cholecalciferol, suggests that in her $N$ case such end organ resistance was acquired and secondary to vitamin $\mathrm{D}$ deficiency.

Decreased renal sensitivity to PTH could be due to altered metabolism of vitamin $\mathrm{D}$, the hydroxylated derivatives of which may have a permissive role in the $\stackrel{\circ}{\square}$ renal tubular action of PTH (Holick and DeLuca, $\Phi$ 1974). Hypocalcaemia itself may increase renal $\stackrel{+}{+}$ tubular resorption of $\mathrm{Pi}$, as suggested by the ${ }^{\circ}$ observation that the renal tubular response to PTH may be restored by $\mathrm{Ca}$ infusion in some patients 
with pseudohypoparathyroidism (Rodriguez et al., 1974).

\section{Acknowledgments}

We are grateful to Professor J. A. Strong for his advice and for permission to report this patient under his care. We thank Dr M. A. Preece and Dr J. L. H. O'Riordan for the assays of PTH, cyclic-AMP and 25-OHD. J. A. K. is in receipt of a MRC Clinical Research Fellowship and R. J. W. of the Mary Goodger Research Scholarship.

\section{References}

Addison, G.M., Hales, C.N., Woodhead, J.S. \& O'Riordan, J.L.H. (1971) Immunoradiometric assay of parathyroid hormone. Journal of Endocrinology, 49, 521.

Allen, E.H., Millard, F.J.C. \& Nassim, J.R. (1968) Hypohyperparathyroidism. Archives of Disease in Childhood, 43, 295.

Bijvoet, O.L.M. \& Morgan, D.B. (1971) The tubular reabsorption of phosphate in man. In: Phosphate et Métabolisme Phosphocalcique (Ed. by D. J. Hioco), p. 153. Sandoz, Paris.

Chase, L.R. \& Aurbach, G.D. (1967) Parathyroid function and the renal excretion of 3 '5'-adenylic acid. Proceedings of the National Academy of Sciences (United States of America), 58, 518.

Clark, L.C. \& BeCK, E. (1950) Plasma alkaline phosphatase activity. Journal of Pediatrics, 36, 335.

Costello, J.M. \& DENT, C.E. (1963) Hypo-hyperparathyroidism. Archives of Disease in Childhood, 38, 397.

GreenberG, B.G., Winters, R.W. \& GrahaM, J.B. (1960) The normal range of serum inorganic phosphorus and its utility as a discriminant in the diagnosis of congenital hypophosphatemia. Journal of Clinical Endocrinology and Metabolism, 20, 364.

Holick, M.F. \& DeLuca, H.F. (1974) Vitamin D metabolism. Annual Review of Medicine, 25, 349.

Preece, M.A., O'Riordan, J.L.H., Lawson, D.E.M \& KODICEK, E. (1974) A competitive protein-binding assay for 25-hydroxycholecalciferol and 25-hydroxyergocalciferol in serum. Clinica chimica acta, 54, 235.

Rodriguez, H.J., Villarkeal, H., Klahr, S. \& SlatoPOLSKY, E. (1974) Pseudohypoparathyroidism type II; restoration of normal renal responsiveness to parathyroid hormone by calcium administration. Journal of Clinical Endocrinology and Metabolism, 39, 693.

RouND, J.M. (1973) Plasma calcium, magnesium, phosphorus and alkaline phosphatase levels in normal British school children. British Medical Journal, 3, 137.

WRONG, O. \& DAVIES, H.E.F. (1959) The excretion of acid in renal disease. Quarterly Journal of Medicine, 28, 259.

\section{Diffuse vasculitis, eosinophilia, and elevated antibody titre to measles virus}

\author{
R. C. BUCKNALL* \\ M.B., B.S., M.R.C.P.
}

R. DosHI $\dagger$

M.B., B.S., M.R.C.Path., D.Path.

The Departments of General Medicine and Neuropathology, Frenchay Hospital, Bristol

\section{Summary}

In the original description of serum sickness by Von Pirquet and Schick (1905) vasculitis was described as a feature. This was subsequently shown to be due to circulating immune complexes, which are known to be eosinotactic. The following report describes a case of serum sickness, occurring in a 14-year-old boy, characterized by diffuse vasculitis with communicating hydrocephalus and accompanied by a pronounced eosinophilia. A significantly raised antibody (IgG) titre to measles virus was demonstrated in his serum and

\footnotetext{
* Present appointment: Medical Registrar, Royal National Hospital for Rheumatic Diseases, Bath.

$\dagger$ Present appointment: Consultant Neuropathologist, The Maudsley and The Brook General Hospitals, London.

Correspondence: Dr R. C. Bucknall, Royal National Hospital for Rheumatic Diseases, Upper Borough Walls, Bath, Somerset.
}

indicated that this agent probably provided the initial antigenic stimulus.

\section{Case report}

A 14-year-old white boy of English parentage was admitted as an emergency to the Royal United Hospital, Bath, with a 24-hr history of abdominal pain. This was originally central in position but subsequently radiated to the right iliac fossa. He had also had pain in both sides of the neck. One month before the onset of these symptoms he had had a sore throat and non-productive cough, but no rash. From that time he had remained anorexic and lethargic. There was no previous history of illness except for mild eczema at the age of 2.5 years; this did not persist and there were no other atopic features. $\mathrm{He}$ had had a dry scaly skin since birth and one of his four sisters was similarly affected. He had neither had 